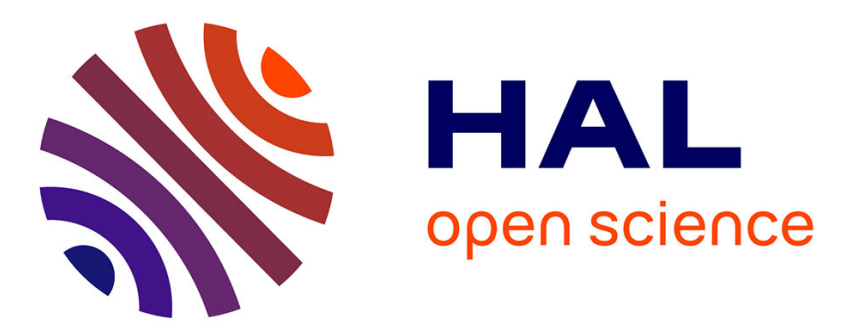

\title{
Bark wounds caused by felling are more susceptible to discoloration and decay than wounds caused by extraction in European beech
}

Ulrike Hecht, Ulrich Kohnle, Michael Nill, Jörg Grüner, Berthold Metzler

\section{- To cite this version:}

Ulrike Hecht, Ulrich Kohnle, Michael Nill, Jörg Grüner, Berthold Metzler. Bark wounds caused by felling are more susceptible to discoloration and decay than wounds caused by extraction in European beech. Annals of Forest Science, 2015, 72 (6), pp.731-740. 10.1007/s13595-014-0432-y . hal-01284207

\section{HAL Id: hal-01284207 \\ https://hal.science/hal-01284207}

Submitted on 7 Mar 2016

HAL is a multi-disciplinary open access archive for the deposit and dissemination of scientific research documents, whether they are published or not. The documents may come from teaching and research institutions in France or abroad, or from public or private research centers.
L'archive ouverte pluridisciplinaire $\mathbf{H A L}$, est destinée au dépôt et à la diffusion de documents scientifiques de niveau recherche, publiés ou non, émanant des établissements d'enseignement et de recherche français ou étrangers, des laboratoires publics ou privés. 


\title{
Bark wounds caused by felling are more susceptible to discoloration and decay than wounds caused by extraction in European beech
}

\author{
Ulrike Hecht • Ulrich Kohnle • Michael Nill • \\ Jörg Grüner • Berthold Metzler
}

Received: 7 February 2014 / Accepted: 14 October 2014 / Published online: 30 October 2014

(C) INRA and Springer-Verlag France 2014

\begin{abstract}
- Key message Beech is subjected to devaluating bark damage by logging operations. It is shown experimentally that damage in the upper part of the trunk entails much higher risk of wood discoloration and decay by fungi than damage in the lower part. Cellular defense mechanisms in xylem are elucidated.

- Context During harvesting operations and more specifically processes of both felling and extraction, remaining trees suffer specific bark damages, leaving the exposed xylem vulnerable to subsequent discoloration and fungal decay. As a consequence, the future value of the produced timber is reduced.

- Aims The objective of this study is to test for the consequences of artificial bark damage to the base vs. the upper parts of the trunk in terms of discoloration, fungal infection, wood decay, and wound closure.

- Methods An artificial basal "extraction wound" was inflicted along with an elongated "felling wound" at 5-m stem height in 40 beech trees (Fagus sylvatica L.) during either June or October. The trees were felled 3 years later and the
\end{abstract}

Handling Editor: Francis Colin

Contribution of the co-authors Ulrike Hecht: laboratory work, data collection and analysis, and writer of the manuscript.

Ulrich Kohnle: intention and coordination of the experiment.

Michael Nill: design and performance of the field experiment.

Jörg Grüner: identification of fungi by PCR, and providing microscopic sections.

Berthold Metzler: supervising lab-work and co-writer of the manuscript, corresponding author.

U. Hecht $\cdot$ U. Kohnle $\cdot$ M. Nill $\cdot$ B. Metzler $(\square)$

Forest Research Institute Baden-Württemberg, Wonnhaldestr.4,

D-79100 Freiburg/Br., Germany

e-mail: berthold.metzler@forst.bwl.de

J. Grüner

Forest Botany Institute, University of Freiburg, Bertoldstrasse 17,

D-79085 Freiburg/Br., Germany impact of the wounds was evaluated with microscopic imaging and microbiological methods.

- Results The compartmentalization observed in the basal extraction wounds was highly efficient, and rate and intensity of discoloration and susceptibility to decay were significantly lower than in wounds inflicted to the upper segments of the trunk. The latter displayed deeply penetrating discoloration and decay.

- Conclusion Bark damage in the higher portions of the stem inflicted by felling is followed by much higher risk of wood discoloration and decay than damage at the base of the stem (extraction damage). Harvesting management has to be optimized in order to avoid felling damage in remaining neighboring trees particularly.

Keywords Fagus sylvatica · Bark damage · Discoloration · Decay $\cdot$ Wood anatomy

\section{Introduction}

European beech (Fagus sylvatica L.) is by far the most important broadleaved tree species in German forests. Among the major crop tree species of southwest Germany, beech showed the highest percentage of standing trees wounded in the upper parts of the stem mostly due to felling damage (16\%; Nill et al. 2011). Combined with the same percentage of extraction damage, $28 \%$ of the beech trees were affected by bark damage. Such bark damage often leads to wood discoloration and decay which reduces the quality of the timber produced from affected stands. Several studies of broadleaved tree species have examined the impact of bark damage occurring at the butt of the trunk (e.g., Schulz 1973; Schumann and Dimitri 1993), but few studies have addressed the effects of mechanical damage to bark on the upper parts of the stem. Anecdotal evidence from forest practitioners suggests that 
bark wounds inflicted when the bases of trunks are struck by felled stems being hauled from a stand (referred to as "extraction damage") are less liable to give rise to wood decay than the elongated bark wounds caused when the upper regions of standing stems are struck by falling trees during thinning operations (referred to as "felling damage") (Knorr and Prien 1988; Schulz 1973). Other agents of bark damage in beech such as peeling deer or activities of small animals like fat dormouse (Glis glis) are considered less important in Germany.

The complex physiological defense reactions of trees after wounding were first outlined by Shigo and Hillis (1973) and refined by Shigo and Marx (1977). Their CODIT model describes how, following an injury, the tree protects itself by forming reaction zones or boundaries (also referred to as "walls 1-4") which limit the expansion of infection. The model was subsequently enhanced by Rayner and Boddy (1988) and Liese and Dujesiefken (1996) who stressed the reaction of the tree to "damage" encompassing not only decay but also the preceding processes of desiccation and dysfunction of woody tissues.

The objective of our study was to compare the consequences of bark damage to the base and upper parts of the trunk in beech trees in order to determine whether differences in the degree of discoloration, fungal infection, wood decay, and wound closure were evident in these different positions on the stem. Furthermore, we aimed to investigate how potential differences might be explained by wood anatomical reactions. It is hypothesized that specific cellular mechanisms might hinder desiccation ensuing from bark damage under certain conditions. To this end, artificial wounds were created at two different positions on the stems of intact beech trees and destructively analyzed after 3 years. Our primary objective was to assess the validity of the practitioners' claim that beech is differently impacted by extraction and felling wounds. We therefore attempted to conduct our experiment under as close as possible ceteris paribus conditions and synchronously placed both types of bark wounds on the same trees. Furthermore, the wounds were created at two different dates to address the possible impact of the season of wounding.

\section{Material and methods}

In 2006, 40 trees in a beech (F. sylvatica) stand growing on an eastern slope in Southwest Germany (Black Forest, Kreis Breisgau-Hochschwarzwald; GK-coordinates: N 47.325394, E 8.019826) were selected for the experimental study. The stand consisted of beech approximately 80 years old and was situated at an elevation of ca. $980 \mathrm{~m}$ above sea level. For each tree, diameter at breast height (ca. $1.3 \mathrm{~m}$; "dbh") was measured, and the competition status (Kraft class) was recorded.
Trees with visually discernible bark wounds were excluded from the experiment.

Artificial bark wounds were created at 20 of the selected trees at the beginning of the 2006 growing season (June 1), with the remaining 20 trees receiving the same treatment at the end of the same growing season (October 9). Wounds were made at two different positions on each stem: a patch of bark $\left(34 \times 13 \mathrm{~cm}=442 \mathrm{~cm}^{2}\right)$ was removed ca. $0.5 \mathrm{~m}$ above ground level to simulate an extraction wound and an elongated strip of bark with an identical surface area $\left(68 \times 6.5 \mathrm{~cm}=442 \mathrm{~cm}^{2}\right)$ at a height of 5-6 m above ground level to simulate a felling wound. In all cases, the wounding process consisted of scribing the outline of the area of bark to be removed using a carpet knife and carefully prising off the outer bark and phloem within the outline in order to expose the xylem surface without damaging the xylem itself.

The dimensions of the artificially created wounds were selected to correspond as well as possible in terms of shape and size with extraction and felling wounds inflicted unintentionally during real harvesting operations (Schumann and Dimitri 1993). To further mimic real-world damage, all experimental wounds were created on the up-slope sides of the stems where the majority of wounds inflicted during logging activities or rock fall would occur.

In October 2009, all 40 trees were felled, having remained in situ for four (June 2006 wounds) or three (October 2006 wounds) growing seasons after the wounding treatment. For each tree, cross-sectional discs (4-6-cm thick) were removed from the mid-points of both bark wounds (Figs. 1 and 2). A third disc was removed from each stem at breast height after

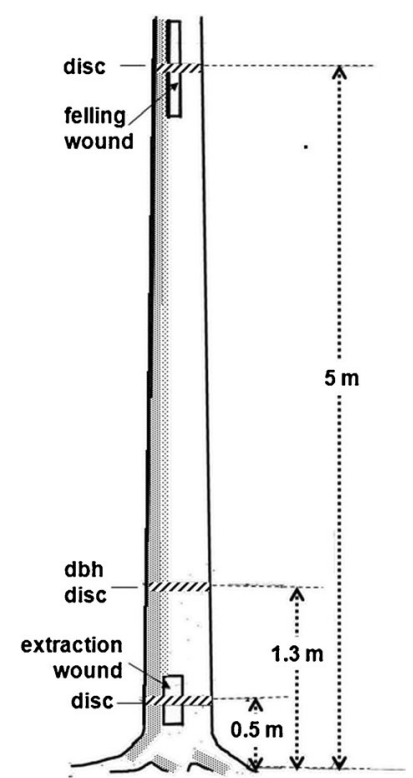

Fig. 1 Experimental design for inflicting the bark wounds at the base of the stem ("extraction wound") and at $5 \mathrm{~m}$ tree height ("felling wound"). Tree discs were sampled from the center of the wound areas and from breast height $(\mathrm{dbh})$ of the harvested beech stems 


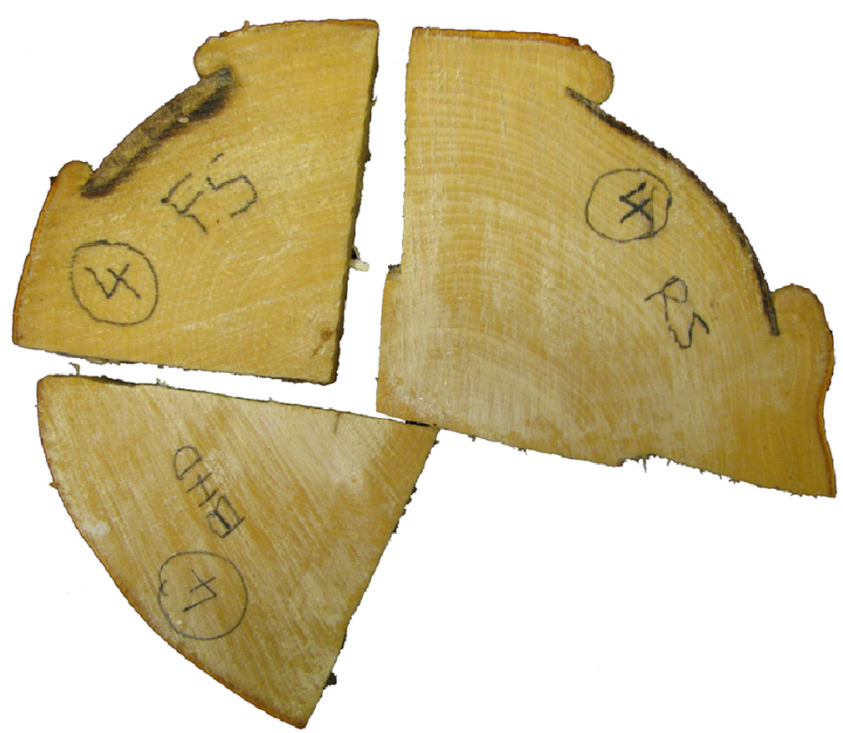

Fig. 2 Scheme of sampling in each tree (example tree no. 4): wood discs from extraction wound $(R S)$, felling wound $(F S)$, and at breast height $(\mathrm{dbh}=\mathrm{BHD})$. Note the typical narrow reaction zone close to the surface below the extraction wound $(R S)$ and in contrast the thicker discoloration and decay zone exceeding a depth of $0.5 \mathrm{~cm}$ below the felling wound $(F S)$. The dbh disc is void of any symptoms

marking its alignment with the position of the lower and upper wounds. All discs were frozen at $-8{ }^{\circ} \mathrm{C}$ and thawed immediately before further investigation. The occurrence of wood discoloration and decay in each disc was checked through visual inspection and, if present, the extent was recorded (Metzler et al. 2012). The radial depth of wood discoloration in the center of the wound, as well as in marginal and peripheral positions, was recorded in the form of three classes $(<0.5$, $0.5-4.0$, and $>4.0 \mathrm{~cm}$ ). Furthermore, it was also documented if any discoloration was visually discernible in the disc cut at breast height. Discoloration in the center of the stem judged to have obviously been present before the wounding treatments (e.g., discoloration associated with branch stubs or "red heart" typical for beech) was discarded from the assessment of discoloration related to the artificial bark wound. Furthermore, the presence of vertical discoloration columns was checked in six 1-m-long log sections which were cut off adjacent to the extraction, respectively, felling wounds and were sawed longitudinally through the wound area.

In order to identify any changes in the wood structure associated with the experimental wounds, selected wood samples $(0.5$-cm deep) were taken from the xylem surface which had been exposed by removal of the bark (Fig. 3). Thin sections were cut from the samples by hand or, after fixation in glutaraldehyde and embedding in epoxy resin, were cut using a microtome and subjected to microscopic examination. Embedded material was stained according to the protocol described in Schwarze et al. (1995) to aid visualization.

For isolation of fungi, a scheme of sampling based on previous studies described in Metzler et al. (2012) was

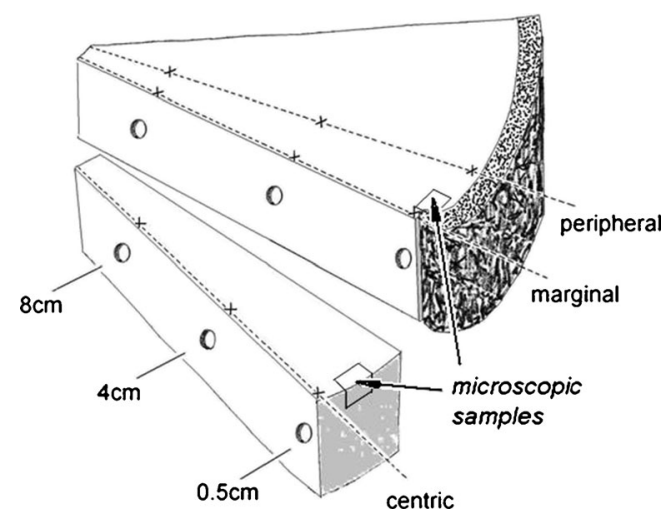

Fig. 3 Sampling scheme for isolation pieces which were taken from different depths inside the stem discs. Also, microscopic samples were taken from the wound surface (including reaction zone) and from the barrier zone at the edge of the wound (redrawn from Metzler et al. 2012)

employed. A total of 840 isolation pieces were obtained from the 80 wound-discs and 40 breast-height discs immediately after thawing in order to isolate wood-colonizing fungi as follows: The wood discs from wound level were split radially according to the previously mentioned scheme in central, marginal, and peripheral positions (Fig. 3) relative to the wound by means of a rack and pinion press equipped with a chisel. Immediately after splitting (Metzler 1997a), the isolation pieces were obtained by punching platelets of ca. $12 \mathrm{~mm}^{3}$ from the freshly exposed wood surface using a 4-mm diameter cork borer under sterile conditions in a laminar-flow hood. Isolation pieces were taken at depths of $0.5,4.0$, and $8.0 \mathrm{~cm}$ behind the wound surface. Thus, nine samples were taken for investigation from each wound-disc ( 3 positions $\times 3$ depths). The breast-height discs were sampled in the same manner, but only along a single radial split corresponding with the alignment mark created prior to felling, thus yielding three isolation pieces ( 1 position $\times 3$ depths). Microbiologic processing of these samples was done according to Metzler et al. (1993, 2012). Characterization and identification of the fungal isolates was performed microscopically. Identification of wood decay fungi was verified by PCR by use of the primers ITS5 and ITS4.

The progress of wound closure was measured on the wood discs at both lateral margins of each wound, and the mean value of lateral closure was noted.

\section{Results}

\subsection{Discoloration and decay}

Superficial xylem discoloration of at least a few millimeters in depth occurred in the central and marginal positions of the inflicted wounds in almost all cases (Table 1). All extraction wounds inflicted in June showed discoloration to a depth of at least $0.5 \mathrm{~cm}$ underneath the surface of the wound at its center 
Table 1 Radial extension of discoloration and decay inside central (centr), marginal (marg), and peripheral (peri) wound area (\% of examined tree discs) of extraction and felling damage in beech (June versus October)

\begin{tabular}{|c|c|c|c|c|c|c|c|c|c|c|c|c|}
\hline \multirow{4}{*}{$\begin{array}{l}\text { Number of discs } \\
\text { Radial depth }\end{array}$} & \multicolumn{6}{|c|}{ Extraction damage } & \multicolumn{6}{|c|}{ Felling damage } \\
\hline & \multicolumn{3}{|l|}{ June } & \multicolumn{3}{|c|}{ October } & \multicolumn{3}{|l|}{ June } & \multicolumn{3}{|c|}{ October } \\
\hline & \multicolumn{3}{|l|}{20} & \multicolumn{3}{|l|}{20} & \multicolumn{3}{|l|}{20} & \multicolumn{3}{|l|}{20} \\
\hline & centr & marg & peri & centr & marg & peri & centr & marg & peri & centr & marg & peri \\
\hline$<0.5 \mathrm{~cm}$ & 100 & 100 & 0 & 70 & 95 & 0 & 100 & 100 & 0 & 100 & 100 & 0 \\
\hline$<4.0 \mathrm{~cm}$ & 35 & 15 & 0 & 15 & 0 & 0 & 80 & 80 & 0 & 80 & 55 & 0 \\
\hline$>4.0 \mathrm{~cm}$ & 0 & 0 & 0 & 0 & 0 & 0 & 25 & 25 & 0 & 0 & 0 & 0 \\
\hline$>8.0 \mathrm{~cm}$ & 0 & 0 & 0 & 0 & 0 & 0 & 15 & 15 & 15 & 0 & 0 & 0 \\
\hline
\end{tabular}

(Fig. 2). In contrast, only $70 \%$ of the October wounds of the same type were discolored. Discoloration exceeding a depth of 0.5 occurred in $35 \%$ of the June wounds, compared to only $15 \%$ of the October wounds. However, in none of the extraction wounds (June or October) did discoloration reach deeper than $4 \mathrm{~cm}$ beneath the surface at the wound center (Table 1).

For felling wounds, the radial extent of discoloration of the xylem was clearly greater than for the extraction wounds. All discs (June as well as October wounding) showed discoloration to a depth of at least $0.5 \mathrm{~cm}$ behind beneath the wound's surface in the central and the marginal positions (Table 1). Discoloration deeper than $4 \mathrm{~cm}$ was evident in $25 \%$ of the June wounds. This is significantly more severe than in the October wounds and in the respective wound site of extraction wounds $\left(\chi^{2}=5.7 ; P=0.016\right)$. Fifteen percent of the June wounds displayed discoloration which extended to more than $8 \mathrm{~cm}$ in depth. A distinct wedge-shaped zone of discoloration with symptoms of decay was observed in five of the discs ( $25 \%)$ due to the June wounding treatment. In three of these discs, the discoloration associated with the wound broadened at about 8-cm depth in connection with internal fissures and was therefore detectable in the peripheral sampling position. Larger portions of the discoloration were delimited by a distinctive marginal zone (Fig. 4). Otherwise, no peripheral extension of discoloration or decay was noted. In the discs originating from the October wounding treatment, none of the discoloration or decay reached further than $4 \mathrm{~cm}$ into the xylem.

Axial extension of discoloration associated with wounds took the form of spindle-shaped columns of stained xylem extending both above and below the wounding sites. With increasing distance from the wounded area, the dark shaded discoloration decreased in extent. None of the 40 breast-height discs, which were located $80 \mathrm{~cm}$ above the upper margin of the simulated extraction damage, displayed any discoloration; in one of the extraction wounds in which this dark shaded zone of discoloration was examined in detail, the discoloration extended for only $1.5 \mathrm{~cm}$ below and above the site of the wound. In the five felling wounds which were examined in detail for the axial extent of the discoloration columns, the length of this column varied from 6 to $62 \mathrm{~cm}$ equally above and below the upper and the lower margins of the surface wound.

Microscopic examination of cross sections revealed dark discoloration within several annual rings formed prior to the year of wounding: In the June wounds which were investigated, the cell lumina of vessels formed in the 5 years preceding treatment were blocked by tyloses. The most intensive formation of tyloses was concentrated in the vessels of the third, fourth, and fifth annual rings below the wound surface, forming distinct boundaries including tangentially orientated chains of axial parenchyma cells which were filled with polyphenolic deposits of a reddish-brown color (Fig. 5). These

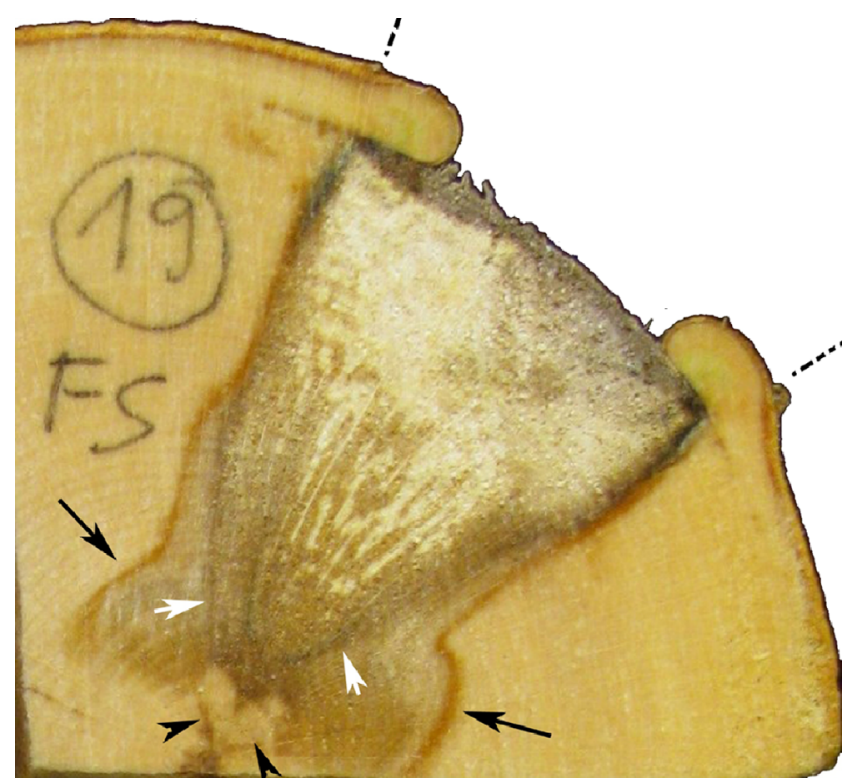

Fig. 4 Typical wedge-shaped discoloration (reaction zone) and decay inside a felling wound (dotted lines). In the center of the stem, the discolored area is even extending, probably due to internal fissures (black arrowheads) in the stem center (lower margin). Note the primary (white arrows) and secondary (black arrows) marginal zones 


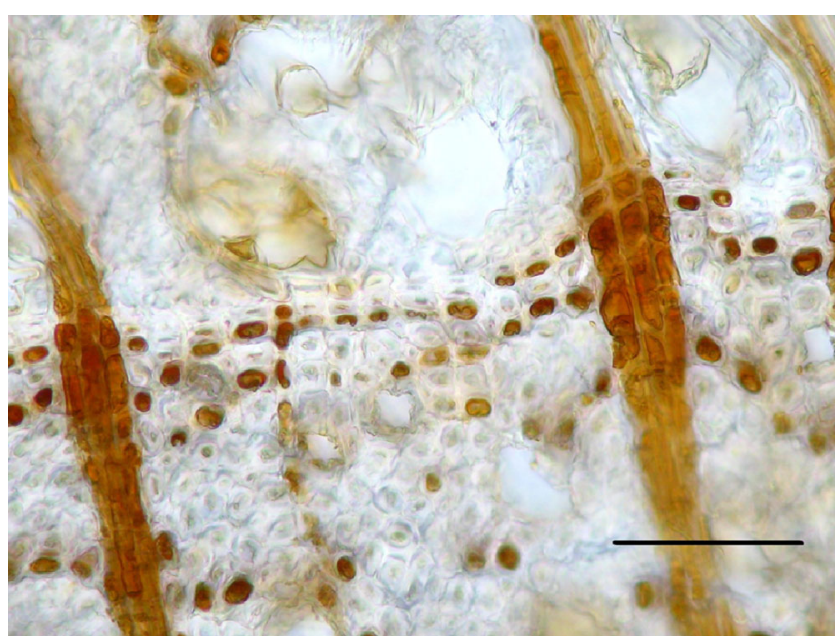

Fig. 5 Microscopic investigation of June wounds (extraction damage): note the reaction zone: series of tangential bands of axial parenchyma cells, containing oxidized (reddish-brown colored) phenolic compounds (unstained section) (scale bar $=100 \mu \mathrm{m})$

chains occurred mainly in the latewood of the second to the fourth year rings. At the lateral margins of the wound, parenchyma cells of the xylem formed prior to wounding were similarly filled with droplets of reddish-brown polyphenols.

Abundant formation of radially orientated wood rays originating from the wound callus tissue was evident in cross sections taken from the peripheral area directly beyond the wound margin (Fig. 6). These cells were also filled with polyphenolic deposits forming long rows in a radial orientation throughout the first increment produced after the year after wounding, and were clearly less frequently observed in the annual ring formed in the second year after wounding. The vessels in the first annual ring after wounding were conspicuously smaller in diameter (ca. $35 \mu \mathrm{m}$ ) than in the xylem before wounding (ca. $50 \mu \mathrm{m}$ ) and were not blocked by tyloses. In the second year after wounding, the size of the vessels was back to normal.

Fungal hyphae could mainly be observed close to the wound surface in the early wood of the annual ring formed in the year of wounding but occasionally also in the latewood of the preceding year's ring. Pigmented fungal hyphae were abundant in the outermost annual ring below the wound surface which was void of brown polyphenolic substances. The cell walls of colonized parenchyma cells were partially decayed by boring hyphae. Hyphae were not observed beyond the reaction zone of the wound area. Furthermore, the increment outside the barrier zone (or "wall 4" according to the CODIT model) was void of hyphae. Cross sections taken from the October wounds showed a similar pattern of brown phenolic substances in chain-like rows of parenchyma cells and in fiber tracheids. The chains of polyphenol-containing cells were confined to the two annual rings immediately below the wound surface, yet the vessels were blocked by tyloses up to the third growth ring.

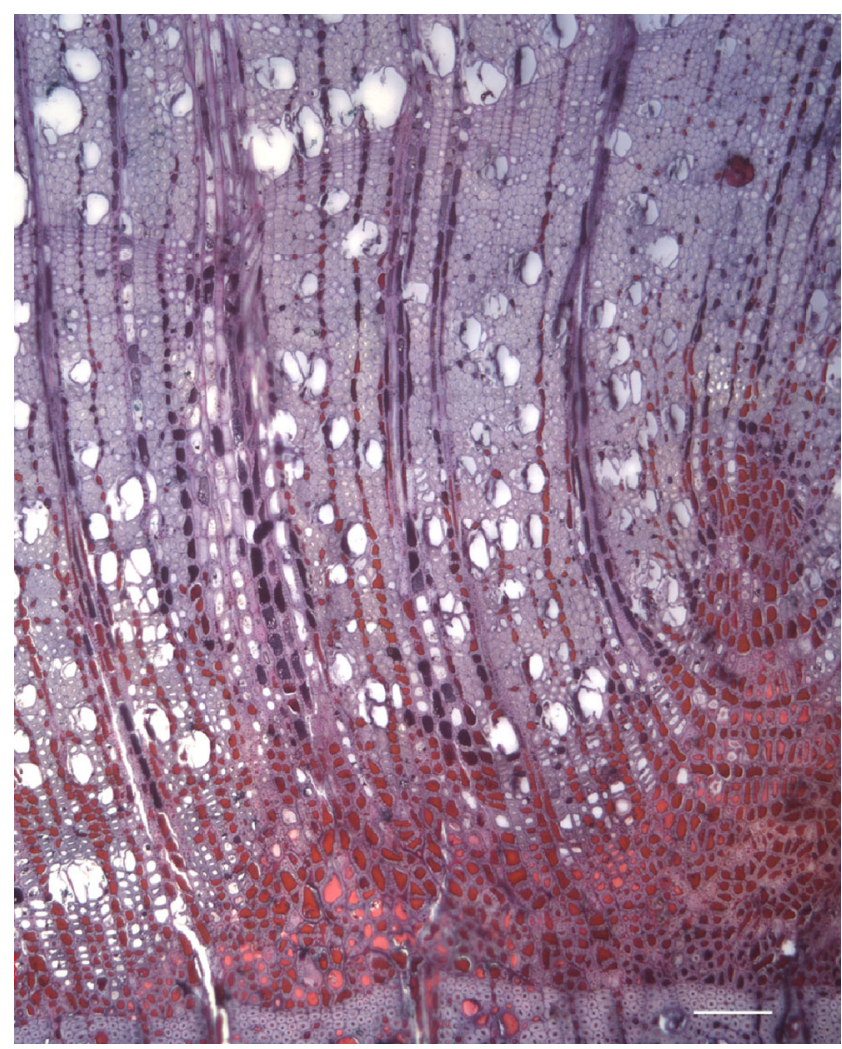

Fig. 6 Microscopic view of callus tissue initial at the very wound edge. Radial wood rays and parenchyma cells with polyphenols within the first and second year's increment distal of wound (barrier zone at figure bottom). Note the smaller size of vessels in the first year's increment in contrast to the vessels of normal diameter in the second year (scale bar $=100 \mu \mathrm{m}$ )

\subsection{Fungal colonization of wounds}

In the simulated extraction wounds, fungal isolates were obtained from $11 \%$ (39 out of 360) of isolation pieces (Table 2). Contrastingly, approximately twice as many samples were found to be infected $(22 \% ; 80 / 360)$ in the simulated felling wounds. Statistically, this difference in the frequency of infection within extraction and felling wounds was highly significant $\left(\chi^{2}=16.92 ; P<0.001\right)$. In extraction wounds, fungal infection appeared to be superficial in most cases. With respect to the season of wounding (June vs. October), the difference of the number of isolates was not statistically significant. However, from the breast-height discs, where no bark damage had been inflicted, only $3 \%(4 / 120)$ of the isolation pieces yielded fungal isolates. This was highly significant when compared with extraction $\left(\chi^{2}=6.21 ; P=0.012\right)$ as well as felling damage $\left(\chi^{2}=22.24 ; P<0.001\right)$.

In terms of the ecological groups of the isolated fungi, wood decay fungi were represented most frequently by 2 species of the ascomycete genus Hypoxylon-Hypoxylon fragiforme (17 isolates) and Hypoxylon cohaerens (5 isolates) - with 3 isolates of the basidiomycete Cylindrobasidium 
Table 2 Number of fungal isolates of a predetermined number of xylem isolation pieces from injured beech trees
Note the high rate of wood decay fungi in felling damage wounds inflicted in June

\begin{tabular}{|c|c|c|c|c|c|c|}
\hline \multirow[b]{2}{*}{ Season of wounding } & \multicolumn{2}{|c|}{ Extraction wounds } & \multicolumn{2}{|c|}{ Breast height } & \multicolumn{2}{|c|}{ Felling wounds } \\
\hline & June & October & June & October & June & October \\
\hline Number of investigated trees & 20 & 20 & 20 & 20 & 20 & 20 \\
\hline Number of isolation pieces & 180 & 180 & 60 & 60 & 180 & 180 \\
\hline Number of isolation pieces with fungal isolates & 17 & 22 & 0 & 4 & 45 & 35 \\
\hline$\%$ isolation pieces without fungal isolates & 90.5 & 87.7 & 100 & 93.3 & 75 & 80.5 \\
\hline \multicolumn{7}{|l|}{ Wood decay fungi } \\
\hline Hypoxylon fragiforme & 1 & 0 & 0 & 1 & 15 & 0 \\
\hline Hypoxylon cohaerens & 1 & 0 & 0 & 0 & 4 & 0 \\
\hline Cylindrobasidium evolvens & 0 & 0 & 0 & 0 & 2 & 1 \\
\hline Undetermined Basidiomycetes & 1 & 2 & 0 & 0 & 0 & 0 \\
\hline \multicolumn{7}{|l|}{ Bluestain fungi } \\
\hline Phoma spp. & 5 & 9 & 0 & 1 & 10 & 17 \\
\hline Phialophora spp. & 2 & 4 & 0 & 0 & 1 & 2 \\
\hline $\begin{array}{l}\text { Rare or undetermined } \\
\text { bluestain fungi }\end{array}$ & 1 & 3 & 0 & 1 & 2 & 2 \\
\hline \multicolumn{7}{|l|}{ Other fungi } \\
\hline Acremonium spp. & 1 & 1 & 0 & 0 & 3 & 1 \\
\hline Apiognomonia errabunda & 3 & 6 & 0 & 0 & 7 & 6 \\
\hline Phomopsis sp. & 0 & 0 & 0 & 0 & 0 & 2 \\
\hline $\begin{array}{l}\text { Rare or undetermined } \\
\text { other fungi }\end{array}$ & 4 & 2 & 0 & 2 & 3 & 8 \\
\hline Total number of fungal isolates & 19 & 27 & 0 & 5 & 47 & 39 \\
\hline
\end{tabular}

evolvens also being obtained. These species were rarely isolated from extraction wounds, and (if given) only close to the surface of the wound $(0.5 \mathrm{~cm})$, but were obtained significantly more frequently from the wood of felling wounds $\left(\chi^{2}=11.2\right.$; $P<0.01$ )

With respect to the distribution of fungal isolates, the stem discs with felling wounds clearly showed a higher rate of superficial fungal colonization (Table 3). In the central position of felling wounds, $20 \%$ of the isolated fungi were wood-decaying species (extraction damage,
$7.5 \%$ ). At a depth of $4 \mathrm{~cm}$ beneath the wound surface, wood decay fungi were isolated from felling wounds in $10 \%$ of the discs (extraction damage, $0 \% ; \chi^{2}=4.2 ; P=$ $0.04)$. Twenty-one isolates of wood decay fungi were obtained from the discs of June wounds (19 of these being of Hypoxylon spp.), whereas only 1 disc of the October wounds was infected with a wood-decaying fungus.

For bluestain fungi, the proportion of isolates was approximately $30 \%$ higher in felling wounds than in extraction
Table 3 Occurrence of isolates of ecological groups of fungi in different radial depth of beech xylem $(\%$ of investigated tree discs, total of both seasons of wounding)

In felling wounds, more fungal isolates could be obtained from deeper positions in the wood, especially in the central and marginal area of the wounds as compared to extraction wounds

\begin{tabular}{|c|c|c|c|c|c|c|c|}
\hline & \multirow[b]{2}{*}{$\begin{array}{l}\text { Radial depth } \\
\text { below wound }\end{array}$} & \multicolumn{3}{|c|}{ Extraction wounds $(n=40)$} & \multicolumn{3}{|c|}{ Felling wounds $(n=40)$} \\
\hline & & Central & Marginal & Peripheral & Central & Marginal & Peripheral \\
\hline \multirow[t]{3}{*}{ Wood decay fungi } & $0.5 \mathrm{~cm}$ & 7.5 & 2.5 & 2.5 & 20 & 10 & 0 \\
\hline & $4.0 \mathrm{~cm}$ & 0 & 0 & 0 & 10 & 2.5 & 0 \\
\hline & $8.0 \mathrm{~cm}$ & 0 & 0 & 0 & 7.5 & 5 & 0 \\
\hline \multirow[t]{3}{*}{ Bluestain fungi } & $0.5 \mathrm{~cm}$ & 30 & 15 & 0 & 25 & 27.5 & 5 \\
\hline & $4.0 \mathrm{~cm}$ & 0 & 0 & 5 & 0 & 10 & 2.5 \\
\hline & $8.0 \mathrm{~cm}$ & 2.5 & 0 & 10 & 10 & 2.5 & 0 \\
\hline \multirow[t]{3}{*}{ Other fungi } & $0.5 \mathrm{~cm}$ & 32.5 & 5 & 5 & 62.5 & 2.5 & 0 \\
\hline & $4.0 \mathrm{~cm}$ & 0 & 0 & 0 & 2.5 & 0 & 0 \\
\hline & $8.0 \mathrm{~cm}$ & 0 & 0 & 0 & 7.5 & 0 & 0 \\
\hline
\end{tabular}


wounds (Table 2). In extraction wounds, bluestain fungi were detected mostly near the surface, only in one case as deep as $8.0 \mathrm{~cm}$ beneath the stem surface. Phoma spp. and Phialophora spp. were the most frequent genera in this group and were also isolated from greater depths $(>8 \mathrm{~cm})$ beneath the surface of felling wounds (Table 3).

With regard to the group of "other fungi," more than twice as many fungal isolates were obtained from felling wounds than extraction wounds $\left(\chi^{2}=7.2 ; P=0.0066\right)$. A remarkably high proportion of stem discs (62\%) from felling wounds displayed such infections close to the wound's surface at $0.5 \mathrm{~cm}$ or less. These were accounted for to $43 \%$ by Apiognomonia errabunda, which was detected exclusively from this superficial position in the stem discs.

\subsection{Wound closure}

By the time of harvesting, callus had grown on average $13.1 \mathrm{~mm}$ at the lateral margins of all 40 extraction wounds. Wounds which had been inflicted in June 2006 (harvested four growing seasons after wounding) displayed on average a lateral extension of callus of $14.8 \mathrm{~mm}(3.7 \mathrm{~mm}$ on average per growing season). Wounds inflicted 4 months later (October 2006; harvested three growing seasons after wounding) averaged $12.4 \mathrm{~mm}$ of callus growth $(4.1 \mathrm{~mm}$ per growing season) per lateral wound margin (Fig. 7). For the felling wounds, we observed a significantly slower callus growth with an average of $9.4 \mathrm{~mm}$ of callus closure at the lateral wound margin: $10.3 \mathrm{~mm}$ for June wounds $(2.7 \mathrm{~mm}$ per vegetation period), and $8.5 \mathrm{~mm}$ for October wounds ( $2.8 \mathrm{~mm}$ per vegetation period), respectively. The $95 \%$ confidence intervals for the mean rates of callus growth at the margins of

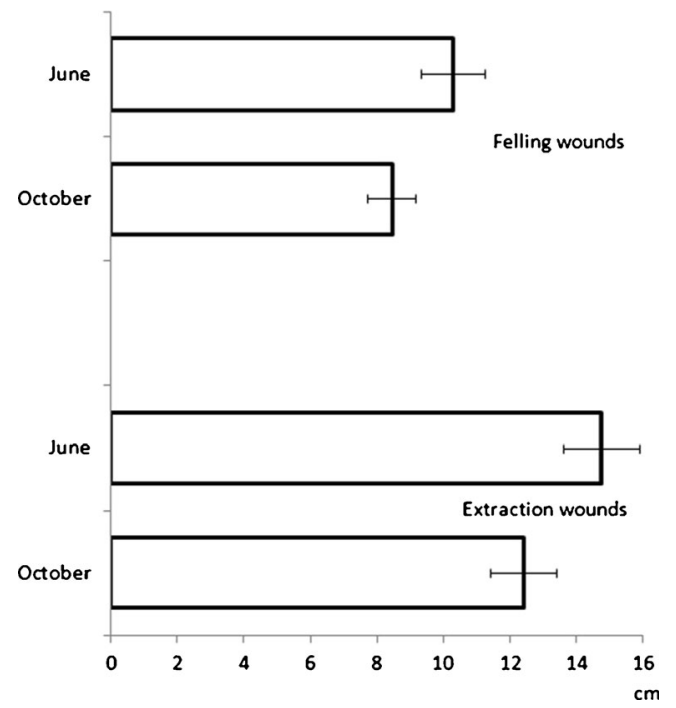

Fig. 7 Total progress of wound healing (unilateral means) in felling and extraction wounds; error bars: $95 \%$ confidence intervals. The duration of the experiment has been three (wounds inflicted in October), respectively, four vegetation periods (wounds inflicted in June) extraction respective felling wounds did not overlap. This indicates a significantly different speed of wound closure at these different treatments. From visual inspection of the wounds, it was evident that wound closure was almost exclusively driven by callus formation at the lateral wound edges, whereas callus formation at the upper and lower edge of the wounds was rather scarce (Fig. 2).

\section{Discussion}

\subsection{Wood discoloration and decay}

In broadleaved trees, defense mechanisms after wounding are usually rather pronounced involving the formation of distinctively pigmented polyphenols due to oxidation of phenolic precursors and flavonoids (Magel et al. 2001), and formation of tyloses (Dujesiefken and Liese 1990; Grosser et al. 1991). In our study, we detected an important functional pattern: in the xylem below, the wound surfaces we observed were thinwalled axial parenchyma cells filled with polyphenols that appear like tangentially orientated single-chain rows. They occurred within the reaction zones and seemed to complement efficient compartmentalization. A similar phenomenon is illustrated in the figures of Grünwald et al. (2002) in beech and Grosser et al. (1991) in hornbeam (Carpinus betulus). Perhaps, when filled with oxidized polyphenolic substances, such chains of cells serve as an efficient means of protecting the intact wood against further desiccation and intruding fungi.

Although the problem of wood decay triggered by felling wounds in beech has previously been addressed by Schulz (1973), few studies have investigated the impact of bark damage inflicted at different positions along the stem. Our results clearly indicate that radial wood discoloration, triggered by felling wounds located several meters above the base of the tree trunk, extend more frequently and to greater depths into the xylem than from extraction wounds located at the base of a stem. During our analysis of stem sections containing the elongated felling wounds, we found that these portions exhibited severely discolored wood and were frequently accompanied by evidence of decay, which extended for a considerable depth from the wound surface into the xylem beneath. The longitudinal extension of discoloration in wounded beech is generally limited (Vasiliauskas 2001). However, we found that the discoloration associated with felling wounds extended axially for larger distances beyond the wound margins than discoloration associated with extraction wounds at the base of stems.

The experimental design did not allow clarifying whether these differences between extraction and felling wounds are due to the shape of the wounds or their positions along the stem. However, we speculate that several of the following factors 
might have been involved: It appears possible that it was the elongated shape of the felling wounds which might have resulted in a desiccation process more favorable for fungal colonization than the broad extraction wounds. Alternatively, or additionally, the process of desiccation might have been less severe at the base of the trunk than in higher portions of the stem due to differences in hydrostatic pressure, respectively, water tension effects at these locations (Zimmermann et al. 1995; Cruiziat et al. 2002). The smaller extent of discoloration in extraction wounds gives evidence that desiccation at the stem base was strictly limited. Thus, discoloration and formation of a reaction zone was confined close to the wound surface and no deeper fungal penetration was detected. Here, the wound surface appeared to be effectively sealed by polyphenolic substances in parenchymatic cells and by tyloses obstructing the vessels.

In the year of initiation of the experiment (2006), the treated trees were exposed to quite unusual aridity when the June wounding treatment was applied. For June and July, a mean temperature with +2.4 and $+5.8^{\circ} \mathrm{K}$, respectively, above the long-term-mean combined with only 30 and $20 \%$, respectively, of the mean precipitation reported for the region (DWD 2006). For October 2006, the mean temperature was $+3.4^{\circ} \mathrm{K}$ above the mean, but the precipitation was $200 \%$. It therefore appears possible that the conditions in June led to rapid desiccation of the wound surface causing the subsequent defense reactions by formation of tyloses to occur deeper within the xylem than would usually be the case. Furthermore, large wedge-shaped zones of discoloration with progressive decay were found exclusively among the June wounds. In three cases, the wedge-shaped discoloration broadened deeply within the xylem into peripheral positions. Here, it appeared that the discoloration caused by wounding intersected with previously formed internal fissures (Fig. 4). Thus, the continuity of the reaction zone was interrupted and oxygen as well as fungi could spread further. Larger zones of discoloration associated with June wounds were also described by Metzler and Ehring (2006) in relation to pruning experiments conducted on walnut (Juglans regia). Seasonal differences in the content of nonstructural components in the sapwood are proved by Barbaroux et al. (2003). However, the factor of desiccation seems to be the principal factor which allows the decay fungi to enter especially in wounds of the upper part of the trunk.

However, based upon empirical observations, this may only hold true if extraction wounds are restricted to bark lesions leaving the xylem essentially undisturbed: Sachsse and Simonsen (1981) reported that if wounding included severe xylem damage, a discolored sector which extended $25 \mathrm{~cm}$ above the wound could generally be found within 1 year.

\subsection{Wound colonizing fungi}

Following desiccation, the invasion of microorganisms will proceed with wood decay fungi being of principal interest. In our comparative analysis, we obtained twice as many fungal isolates from the felling wounds than the extraction wounds. This might be explained by the more intensive desiccation of the felling wounds, thus providing easy access for fungal infection. In our study, we observed deeper discoloration in the xylem of the felling wounds. Five of the 40 felling wounds (13\%) showed complete radially intruding sectors of discoloration and decay.

The consistent sampling of three different tangential wound regions (central, marginal, and peripheral), and additionally at three different radial depths provided strictly comparable data on the radial distribution of fungal isolates in the wound area. Three years after inflicting the bark wounds, it could be seen that the felling wounds (located several meters above the stem base) were colonized three times as often by wood decay fungi than the extraction wounds at the bases of the stems. The total number of isolates obtained from the upper felling wounds was nearly twice as high as from the extraction wounds at the lower stem portion. This observation is clearly related to the larger extent of the discoloration zones observed in the felling wounds and agrees with the CODIT principal of compartmentalization. In accordance with the investigations of Grosser et al. (1991) in relation to the "protection wood" of broadleaved trees, we could not detect fungal penetration beyond this reaction zone close to the surface of the wound area in extraction wounds.

Considering the season of wounding, wood decay fungi were found more frequently in wounds inflicted in June than in October. This observation is consistent with our finding of discoloration being more frequent and of greater extent in June wounds. In earlier investigations, Metzler et al. (2012) compared fungal frequency in Norway spruce (Picea abies) and silver fir (Abies alba) which had also been artificially wounded in May and October. In that study, a direct comparison similarly showed less fungal colonization after wounding in October, though in spruce and fir, this difference was not statistically significant. The specific occurrence of H. fragiforme and Phoma spp. in June and October wounds of beech, respectively, indicates a specific seasonal influence (e.g., by a different extent of desiccation) rather than the influence of the incubation time.

In our study, the frequent presence of $H$. fragiforme in June wounds appears noteworthy particularly in the case of felling wounds where the species was detected in several instances up to 8 -cm deep in the xylem behind the wound surface. In extraction wounds, only five isolates of wood decay fungi were obtained, all of them located superficially within the wound $(0.5 \mathrm{~cm})$. Clearly, superficial bark wounds on the basal parts of beech stems do not necessarily provide easy access for wood-decaying fungi (Schwarze and Heuser 2006).

For the felling wounds, we obtained quite different results: in contrast to extraction wounds, felling wounds displayed fungal colonization close to their surfaces quite frequently. 
A. errabunda, the most frequently isolated fungal species from this niche, is well-known as a leaf pathogen and also invades young twigs (Toti et al. 1993). Additionally, the fungus has now been shown to possess the ability to colonize bark wounds. However, here, the fungus appears to be confined exclusively to the xylem wound surface. Pigmented fungal hyphae, probably belonging to A errabunda, were abundant in the outermost growth ring below the wound surface. Here, the brown polyphenolic substances seemed to be degraded. Degradation of these substances was shown by Schwarze and Baum (2000) in beech wood which was inoculated with Ganoderma adspersum. Corresponding phenoloxidases may be present in a wide variety of fungi (Butin and Kowalski 1992).

In $25 \%$ of the felling wounds, fungi of all ecological groups were isolated from the depth of $8 \mathrm{~cm}$ in the central sampling position. The sealing of the wound by formation of reaction zones (walls 1 and 2 according to Shigo and Marx 1977) appears to be considerably more efficient in the extraction wounds than in the felling wounds.

\subsection{Wound closure}

When wound closure is compared between the two seasons of wounding, the difference in the lengths of the subsequent observation periods has to be kept in mind: three and a half years (four growing seasons) for the June wounding and 3 years (three growing seasons) for the October wounding. Although callus formation occurred in all wounds, large areas of sapwood which were potentially susceptible to infection by wood-colonizing fungi were still exposed in October 2009. This evaluation holds true for both felling and extraction wounds.

After formation of the callus tissue initially (Fig. 6, Grünwald et al. 2002), the new "wound xylem" was subsequently produced. The respective ray cells were filled with discolored phenolic substances thus forming a radial series of "polyphenol-chains" as a kind of structural defense. Due to formation of the barrier zone, there was hardly any tangential extension of the primary wound margins. Furthermore, the vessels within the first annual ring produced after wounding were smaller than normal. Rademacher et al. (1984) described a similar response pattern in their study on sugar maple (Acer saccharum) and reported that the pattern of wood formation had not completely reverted to normal 2 years after wounding. In contrast, our study showed that for extraction wounds in beech, the size of vessels had reverted to a normal pattern in the second year after wounding, although the wound surfaces were still far from being sealed by callus formation. Callus formation was almost exclusively restricted to the lateral edges of wounds and was negligible at the upper and lower edges where it contributed very little to wound closure. This is completely in accordance with Fink (1999), confirming that wound closure is mainly driven from the lateral edges of the wound.

Interestingly, we found that in comparison to extraction wounds, the process of formation of lateral callus was significantly slower for the felling wounds. Usually, tree vigor-as indicated by radial increment - is the driving force of wound healing (Fink 1999; Metzler 1997b; Neely 1988; Schulz 1973). However, as in our study the paired treatment of trees with extraction and felling wounds allows for direct comparison, we can assume that the tree's growth speed did not vary between the two wound types within the individual tree. Apart from the difference of the wounds' position in height on the stem, the relation of wound width to stem circumference represented a major difference between the two wound types. We speculate that these pronounced differences in the shape of the wounds might at least in part explain the difference in the speed of wound closure. Increasing wound width in relation to stem circumference enhances wound callus formation as was shown by Neely (1988). This appears to be the most plausible driving force rendering healing in the extraction wounds obviously faster than in felling wounds.

\subsection{Conclusion}

Clearly, bark damage inflicted on standing beech during felling operations are seriously detrimental to the future value of the timber: Our study clearly demonstrated that narrow, elongated wounds located on high portions of the stem suffer from a significantly increased susceptibility to wood discoloration and decay as they are strongly affected by desiccation, discoloration, and subsequent invasion by fungi. Furthermore, it is evident that the detrimental consequences extend beyond the visible wound surface. As a consequence, characteristics of the bark surface indicating past felling damage - even if complete occlusion of the wounds has occurred - are clearly indicative of reduced timber quality. Therefore, if the objective is the production of valuable beech timber, it is of utmost importance that felling damage is restricted to a minimum by applying appropriate low-damage techniques (Nakou et al. 2013) and/or by paying particular attention to maintaining future crop trees (Hein et al. 2007) from damage when felling in their vicinity.

Interestingly, bark wounds caused when the bases of trunks are struck by felled stems being hauled from a stand (extraction damage) are - although not completely without negative consequences - less detrimental to future timber quality in beech. The rate and intensity of discoloration and susceptibility to decay are significantly lower in such wounds than in those associated with felling. Furthermore, as these wounds are located at the end of the butt log, they may be cut away prior to marketing without too much loss in timber yield. However, this only holds true if wounds are restricted to the 
bark as extraction wounds including damage to the xylem may result in severe decay and devaluation of the timber.

Acknowledgments We gratefully acknowledge the work of Martin Opitz in setting up the experiment in the field, Oswald Keller and Fridolin Sauter in timber harvest, Klaus Freyler and Ricardo Rivero for preparing the tree discs, Gudrun Seiffert, Gabriele Zipfel (all with the Forest Research Institute of Baden-Württemberg), and Susanne Röske (University of Freiburg) for skilful laboratory assistance. Dr. Steven Hendry/ Forest Research Roslin GB improved the manuscript in terms of language as well as with valuable scientific suggestions.

Funding The study was funded by the Ministerium für Ländlichen Raum Baden-Württemberg.

\section{References}

Barbaroux C, Bréda N, Dufrêne E (2003) Distribution of above-ground and below-ground carbohydrate reserves in adult trees of two contrasting broad-leaved species (Quercus petraea and Fagus sylvatica). New Phytol 157:605-615

Butin H, Kowalski T (1992) Die natürliche Astreinigung und ihre biologischen Voraussetzungen VI. Versuche zum Holzabbau durch Astreiniger-Pilze. Eur J For Pathol 22:174-182

Cruiziat P, Cochard H, Ameglio T (2002) Hydraulic architecture of trees: main concepts and results. Ann For Sci 59:723-752

Dujesiefken D, Liese W (1990) Einfluß der Verletzungszeit auf die Wundheilung bei Buche (Fagus sylvatica L.). Holz Roh Werkst 48:95-99

DWD (2006) WitterungsReport 06/07/2006. Deutscher Wetterdienst Offenbach. 29 pp

Fink S (1999) Pathological and regenerative plant anatomy. Borntraeger Stuttgart Bd. 14/6 $1095 \mathrm{pp}$

Grosser D, Lesnino G, Schulz H (1991) Histologische Untersuchungen über das Schutzholz einheimischer Laubbäume. Holz Roh Werkst 49:65-73

Grünwald C, Stobbe H, Schmitt U (2002) Entwicklungsstufen der seitlichen Wundüberwallung von Laubhölzern. Forstw Cbl 121:50-58

Hein S, Lenk E, Klädtke J, Kohnle U (2007) Z-Baum orientierte Auslesedurchforstung in Buche (Fagus sylvatica L.): Aus-wirkungen auf Qualität Sortenstruktur und Wertleistung. Allg Forst- JZtg 178:1-20

Knorr G, Prien S (1988) Fäll- und Rückeschäden bei der Buchen-vornutzung und Möglichkeiten der Reduzierung. Soz Forstw 38:74-76

Liese W, Dujesiefken D (1996) Wound reactions of trees. In: Raychaudhuri SP, Maramorosch K (eds) Forest trees and palms - disease and control. Oxford \& IBH Publish, New Dehli, pp 21-37

Magel E, Abdel-Latif A, Hampp R (2001) Non-structural carbohydrates and catalytic activities of sucrose metabolizing enzymes in trunks of two Juglans species and their role in heartwood formation. Holzforschung 55:135-145

Metzler B (1997a) Quantitative assessment of fungal colonization in Norway spruce after green pruning. Eur J For Pathol 27:1-27

Metzler B (1997b) Infektionsrisiko und Überwallungszeit bei grüngeästeten Fichten. AFZ/Der Wald 52:149-150

Metzler B, Ehring A (2006) Überwallung Holzverfärbung und Pilzinfektionen nach Grünästung der Walnuss zu verschiedenen Jahreszeiten. Jahrb Baumpflege 2006:219-225

Metzler B, Groß M, Mahler G (1993) Pilzentwicklung in Fichtenholz unter Schutzgasatmosphäre. Eur J For Pathol 23:281289

Metzler B, Hecht U, Nill M, Brüchert F, Fink S, Kohnle U (2012) Comparing Norway spruce and silver fir regarding impact of bark wounds. For Ecol Manag 274:99-107

Nakou A, Nill M, Sauter UH, Kohnle U (2013) Rindenschäden durch Holzernte: Analyse, Modellierung und Evaluierung auf der Basis zweier Praxis-Großversuche. Allg Forst- u J-Ztg 184: 97-112

Neely D (1988) Tree wound closure. J Arboric 14:148-152

Nill M, Kohnle U, Sauter U (2011) Rindenschäden mit mutmaßlichem Bezug zur Holzernte im Spiegel der Betriebsinventuren in BadenWürttemberg. Forstarchiv 82:216-224

Rademacher P, Bauch J, Shigo AL (1984) Characteristics of xylem formed after wounding in Acer Betula and Fagus. IAWA Bull 5: $141-151$

Rayner ADM, Boddy L (1988) Fungal decomposition of wood. Its biology and ecology. John Wiley Chichester 587pp

Sachsse H, Simonsen D (1981) Untersuchung über mögliche Zusammenhänge zwischen mechanischen Stammverletzungen und Kernbildung bei Fagus sylvatica. Forstarchiv 52:179-183

Schulz H (1973) Auswirkung von Rückeschäden an jungen Buchen und Edellaubhölzern. Holzforsch 27:43-47

Schumann G, Dimitri L (1993) Wunden und Wundfäulen bei der Buche. Allg Forstz 48:456-460

Schwarze FWMR, Baum S (2000) Mechanisms of reaction zone penetration by decay fungi in wood of beech (Fagus sylvatica). New Phytol 146:129-140

Schwarze FWMR, Heuser C (2006) Stem wounds-potential entry courts for wood decay fungi? Arboric J 29:101-119

Schwarze FWMR, Lonsdale D, Fink S (1995) Soft rot and multiple Tbranching by the basidiomycete Inonotus hispidus in ash and London plane. Mycol Res 99:813-820

Shigo AL, Hillis WE (1973) Hartwood discoloured wood and microorganisms in living trees. Ann Rev Phytopathol 22:197-222

Shigo AL, Marx HG (1977) Compartmentalization of decay in trees. USDA Serv Agric Inf Bull 405:73p

Toti L, Viret O, Horat G, Petrini O (1993) Detection of the endophyte Discula umbrinella in buds and twigs of Fagus sylvatica. Eur J For Pathol 23:147-152

Vasiliauskas R (2001) Damage to trees due to forestry operations and its pathological significance in temperate forests: a literature review. Forestry 74:319-336

Zimmermann U, Meinzer F, Bentrup FW (1995) How does water ascend in tall trees and other vascular plants? Ann Bot 76:545-551 